\title{
Materialitet og mening \\ En studie av de besøkende på bygdetun
}

\author{
BÅrd KLEPPE*
}

Title: A study of the visitors to small rural museums.

Abstract: Both in Norway and Sweden, there are a large number of small rural museums that aim to tell the story of the local community and that intend to serve as meeting places for the inhabitants. Most of these museums were established in a period when they were heavily influenced by the values shaping society at the time, such as a very prevalent rurally based nationalism.

Based on a master thesis, this article asks what these museums mean to the visitors today, and especially, how the materiality affects the visitors when entering such museums. The article also discusses what challenges this poses to the contemporary, everyday museum practice in museums like these.

Key words: Small rural museums, materiality, audience, identity, experience.

Rundt om i Norge finner vi en rekke større og mindre bygdetun som på ulike måter skal fortelle den enkelte bygds historie og fungere som møteplass for befolkningen. Bygdetuna har i mange år blitt drevet på frivillig basis av historie- og museumslag, men i de senere årene har flere og flere blitt innlemmet i større museumsenheter, blant annet som et resultat av museumsreformen. ${ }^{1}$ På denne måten blir bygdetuna en del av de profesjonelle museenes arbeidsfelt, og virksomheten der må tilpasses de målsetninger som defineres fra statlig, kommunalt og fylkeskommunalt hold. Utfordringene knyttet til bygdetunets formål og målsetning blir dermed et viktig spørsmål blant de faglige museumsansatte og et viktig spørsmål i museologien generelt.

Bygdetuna har likevel i liten grad vært gjenstand for museologisk forskning. Det finnes en rekke bidrag til den lokalhistoriske forskningen, der bygningene og gårdens historie har blitt dokumentert, men det er få studier som belyser bygdetunets rolle i dagens samfunn. Bygdetun har mange likhetstrekk med økomuseer, og flere økomuseer innlemmer også bygdetun som del av sin virksomhet (jf. Maure og Gjestrum 1988). På 90-tallet ble det skrevet en rekke artikler om økomuseumsideologien, men i senere tid har økomuseumstanken blitt viet mindre forskningsmessig 
oppmerksomhet. Det er også gjort få empiriske studier av hvordan publikum erfarer økomuseene.

I en empirisk casestudie av et konkret bygdetun fra 2007 forsøkte jeg gjennom deltagende observasjon og kvalitative intervjuer å finne ut om bygdetunet har betydning for de besøkende i dag, og i så fall hvilken betydning. Gjennom en fenomenologisk innfallsvinkel forsøkte jeg å studere hvorvidt materialiteten, altså hus, gjenstander og ting, gir mening for de som besøker et bygdetun.

I denne artikkelen vil jeg presentere noen av de empiriske funnene, og på bakgrunn av disse, svare på hvordan materialiteten erfares og hvordan den tillegges mening av de besøkende ved et bygdetun $i$ dag. Videre vil jeg med dette som utgangspunkt drøfte hvilke utfrodringer og implikasjoner publikums erfaring av materialiteten medforer for museumspraksisen.

For å belyse hvilken mening bygetuna tillegges i dag, kan det være hensiktsmessig å se litt på hvilken meningssammenheng bygdetuna tidligere har blitt plassert inn i. Ikke minst den gangen de ble etablert.

\section{DEN GANG DA - LITT OM BYGDETUNETS HISTORIE}

Ethvert museum vil gjenspeile de verdiene og forståelser som rådet på den tiden museet ble bygd. Dermed vil ethvert museum også være et museum over seg selv ved at det formidler sin egen eksistens og ideologiene som lå til grunn for dets etablering. For å danne seg et bilde av hvilken betydning bygdemuseene hadde da de ble etablert, skal vi se litt på hvilke verdier som lå til grunn for etableringene.

Det første bygdetunet som ble etablert i Norge, var Trysil bygdetun i Østerdalen som åpnet i 1901. Ungdomslaget Trysalir med Sven
Moren i spissen sto bak stiftinga. Moren var dikter og både i skrift og ideologi svært opptatt av heimstaden, bygda og landet. Ungdomslagene, med deres engasjement for lokalsamfunnene, sto bak en rekke etableringer av bygdetun på denne tiden (jf. Talleraas 2009). Det lokale og det nasjonale var i overgangen til det 20. århundre to viktige referanser for den kulturnasjonalismen som vokste fram. Ifølge historiker Øystein Sørensen (Sørensen i Nerbøvik 1999: 180), fant man denne i to ulike varianter: Ei akademisk sentrumsretning som hyllet bonden og bondesamfunnet, samt ei folkelig periferiretning som tok bygdeverdiene på blodig alvor.

I tråd med en slik todeling kan man også tolke etableringene av museer på denne tiden. Friluftsmuseene, bygdetunets storebror, var akademikernes og borgerskapets måte å hylle det norske på (jf. Hegard 1984), mens bygdetunet ønsket å bevare det norske i egen hjembygd for å vise hvor "norsk" deres bygd var (jf. Ågotnes 2000).

I etterkrigstiden ble det også etablert mange bygdetun. Ungdomslagene var fortsatt en viktig aktør bak etableringene av disse, men også historielag, bondelag, enkeltpersoner og kommuner var initiativtagere. Ideologien bak etableringene var likevel den samme:

I etterkrigstidens nyvåknede nasjonalfølelse fant museene en naturlig plass i byggingen av nasjonstanken. Det trengtes ingen ny ideologisk debatt, museenes eksistensberettigelse og måte å drive på var like selvfølgelig som før,

skriver Talleraas (2009: 274).

Det norske og den nasjonale identiteten var en helt sentral referanseramme for etableringene av de kulturhistoriske museene. Parallelt var bygdas identitet viktig i etableringen av bygde- 
tuna. Dette var store, moderne fortellinger som formidlet en samlende identitet.

Som en parallell til bygdetuna har man i Sverige hembygdgardar. Disse har langt på vei hatt den samme målsetningen og den samme formen som bygdetuna. Hembygdsgårdene har $\mathrm{i}$ likhet med bygdetuna i stor grad vært eid og drevet av lag og foreninger, men i Sverige drives og organiseres disse fortsatt av frivillige organisasjoner, den såkalte hembygdsrörelsen.

\section{Case og metode}

Bakgrunnen for denne artikkelen er en casestudie av et bestemt bygdetun i Norge. Bygdetunet heter Kolbeinstveit og ligger i en liten vestlandskommune nord for Stavanger. Kolbeinstveit har mye til felles med ande norske bygdetun, og er heller ikke ulikt hembygdsgårdar slik vi kjenner dem fra Sverige. Bygdetunet Kolbeinstveit tar utgangspunkt i en lensmannsgård som ble etablert med den bygningsmassen vi finner der nå, rundt 1850 . Dette var i en tid da man tok i bruk nye håndverksteknikker og ny byggeskikk slik at alle funksjoner knyttet til gardsdriften ble samlet i en bygning, mens alle funksjoner knyttet til husholdning ble samlet i en annen (jf. Holmboe 2004). Det hvitmalte innhuset på gården er i to etasjer og inneholder to stuer, et stort kjøkken, soverom (lemen), samt kammers der man oppbevarte mat og klær. Selv om konservatorene ved museet har forsøkt å innrede huset mest mulig i tråd med slik det kunne ha sett ut for hundre år siden, bærer flere av rommene preg av nettopp museumsvirksomheten. Etter at bygdetunet ble etablert som museum i 1955, rev man det gamle kjøkkenet. For at huset skulle gjøre nytte som møteplass, og kanskje også for å gi rommet en "twist" av middelalder, plasserte man et stort gildebord der. Denne fordreiningen av fortiden har man valgt å bevare slik at man også i dag kan samle mange mennesker rundt bordet. ${ }^{2}$

Låven på Kolbeinstveit er satt opp i stavkonstruksjon med lafta fjøs. I første etasje finner man fjøs til sau og kyr samt grisehus. I annen etasje er det et stort rom til oppbevaring av høy og korn. Under fjøset er det møkkakjeller. I dag brukes fjøsene til utstillingslokalet for kunstutstillinger, og av og til arrangeres det konserter der. I annen etasje er det utstilling og høy, som barn kan leke i.

Tunet på Kolbeinstveit er stort og grønt. Her finner man også to loft (stabbur) som ble flyttet til Kolbeinstveit da bygdetunet ble etablert. Et av disse er datert til 1281, og er en av få trebygninger fra middelalderen i landsdelen. På tunet finner man også et nyoppusset toalettbygg pakket inn i et tilflyttet eldhus. På sommerhalvåret kommer det dyr og vertskap til Kolbeinstveit. I den ene enden av tunet går to griser og roter i søla, mens på beite lenger ned går det kalver og lam. Rundt på tunet springer det høner som i løpet av sommeren blir stadig mer fortrolig med sommergjestene. Vertskapet går kledd i klær inspirert av hverdagsmoten på 1800 tallet og guider gjestene rundt på gården. I stuene serveres lokalprodusert tradisjonsmat og egg fra egne høner.

I tiden denne studien ble gjennomført var artikkelforfatteren og hans kone vertskap på Kolbeinstveit. Vi hadde da hatt denne jobben i tre år og selv begynt å undre oss på hva vi egentlig formidlet, og hvilken betydning et stopp på bygdetunet hadde for de besøkende. Metodisk var dette utfordrende i og med at vi var og hadde vært delaktig i å konstruere den virkelighet som skulle studeres. Dermed måtte jeg som forsker innta en refleksiv tilnærming $\mathrm{i}$ og med at jeg ikke bare var tilstede som deltagende observatør, men også som en viktig del av det empiriske grunnlaget. Dette innebar at 


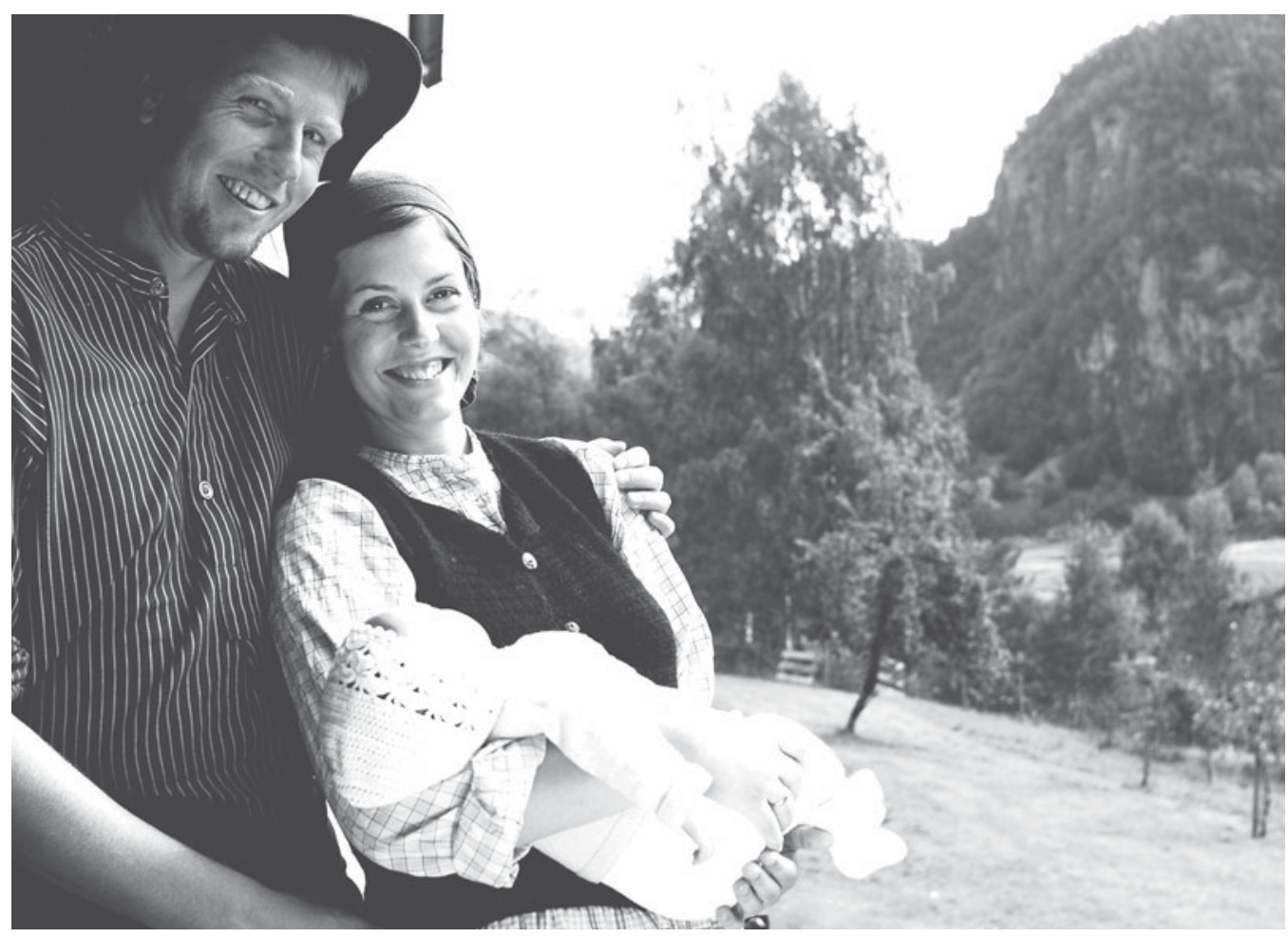

Fig 1: Artikkelforfatteren med kone og datter ønsker de besøkende velkommen til fortidsidyllen. Foto: Anne Lise Nordheim.

også våre tanker og våre holdninger om bygdetunet måtte legges til grunn for analysen. Samtidig gav dette en unik nærhet og kunnskap om forskningsobjektet som viste seg å være positivt (for en ytterligere drøfting av dette, se Kleppe 2007).

På grunn av vår rolle som vertskap ble deltagende observasjonen en viktig metode. En sommer fulgte jeg de besøkende særskilt og gjorde feltnotater etter endt arbeidsdag. Det ble også gjort kvalitative intervjuer med noen av de besøkende. Disse ble plukket ut tilfeldig blant besøkende fra lokalbefolkningen. Utover dette besto det empiriske grunnlaget av skrevne tekster, bilder, museets hjemmesider samt pressedekningen av museet.

\section{MENINGEN I MATERIALITETEN}

Samlingene, gjenstandene, husa og tingene, altså materialiteten, utgjør en helt sentral del av bygdetuna. Det er disse som gir bygdetunet sin egenart, og det er den systematiske innsamlingen og formidlingen av disse som skiller bygdetunet fra et hvilket som helst annet samlingspunkt i lokalsamfunnet. På Kolbeinstveit har man i en årrekke samlet inn gjenstander fra nærmiljøet. På gården finner 
man en rekke landbruksgjenstander, og innhuset er møblert med møbler fra 1800-tallet i et forsøk på å få det til å framstå slik det kan ha sett ut rundt forrige århundre (Holmboe 2004).

De besøkendes forhold til materialiteten og omgivelsene har i senere år blitt gjenstand for interessante bidrag til turismeforskningen og også til museumsforskningen. Geografen Jørgen Ole Bærenholdt gir blant annet en fruktbar gjennomgang av teoretiske innganger til dette feltet i artikkelen At forbinde steder - turistopplevelser på farten (Bærenholdt 2007). Her trekker han frem fire teoretiske vinklinger som kan være fruktbare for å forstå de besøkendes møte med steder: Den mikrososiologiske, den diskurs- og maktorienterte, den fenomenologiske og den fantastiske. I studien av de besøkende på bygdetunet valgte jeg å legge mest vekt på den fenomenologiske tilnærmingen. Dette fordi fenomenologien bryter med det tradisjonelle kartesianske skille mellom subjekt og objekt og på denne måten gir fruktbare rom for tolkninger av de besøkendes forhold til bygdetunet. Den fenomenologisk inspirerte Sosialantropologen Tim Ingold påpeker at "A place owes its character to the experiences it affords to those who spend time there - to the sights, sounds and indeed smells that constitutes its specific ambience" (Ingold 2000: 192). I likhet med Merleau-Ponty og hans kroppsfenomenologi (1962), er Ingold opptatt av at den umiddelbare sansningen er viktig for å forstå folks erfaring av steder og materialitet. Samtidig påpeker Bærenholdt i sin artikkel at Ingolds tilnærming i uforholdsmessig stor grad legger vekt på at mening tilegnes gjennom den enkeltes kropp og sanser. Dette synes som et godt poeng også når man studerer bygdetunet. I og med at stedet, som vi har sett, også har vært meningsbærende gjennom en identitetsdis- kurs og kanskje også gjennom en museumsdiskurs, vil man også finne meninger som er diskursivt knyttet til bygdetunet.

Etnologen Jonas Frykmann og filosofen Nils Gilje etterlyser også mer fenomeonologisk feltarbeid. De påpeker at det har vært mye snakk om fenomenologisk teori, men få som jobber metodisk fenomenologisk. "One does not always have to insist that one is doing phenomenology, but one ought to work phenomenological, that is, descriptively, creatively - intuitively, and in a concretizing manner (Frykman og Gilje 2003: 7). Det var denne oppfordringen jeg forsøkte å ta i min studie.

\section{MATERIALITET OG MUSIKK}

Konserter er et vanlig tilbud på mange bygdetun sommerstid. Det har det også vært på Kolbeinstveit. Per, en av mine informanter, har opp igjennom årene selv vært med å arrangere stevner og konserter på Kolbeinstveit. Når han var med på dette, var han opptatt av at artistene og det kulturelle programmet skulle være bra, men også at det skulle være ekte:

Vi har jo lyst til at folk som kommer hit skal få oppleve noe som er ekte, noe som ikke er kunstig. For dette er ekte. Og hvis vi har et kulturprogram som vi legger litt arbeid i for å få det bra, så blir det en skikkelig pakke. Altså ... Det blir ikke plastikk. Alt ifra mat til underholdning til ramma med bygningene, de solsvarte løeveggene bak. Alt gjør at dette er ekte,

sier Per.

For han er Kolbeinstveit ekte, og da må også programmet være ekte. Det blir ikke plastikk, sier han og hevder samtidig at plastikk ikke er ekte. Bygningene, som utgjør ramma rundt arrangementet, blir heller ikke bare rammer i fysisk forstand. Bygningene med de "solsvar- 
ta" veggene er fulle av betydning. Dermed er også de en del av den "pakka" som tilbys under konsertene. Per tror altså at rammene rundt konserten er svært viktig for konsertopplevelsen. Det kan synes som om Per har mye rett i dette, for også andre blant publikum opplever det slik.

En sommer i 2004 spilte den norske visesangeren Jan Eggum på Kolbeinstveit. Konserten ble holdt $i$ et trangt fjøs møblert med benker fra et bedehus. Veggene, som tidligere varmet kyrne på gården, bærer tydelig preg av slitasjen fra disse, og lukta av nyslått høy siver ned fra annen etasje. Lokalet er lite, og dersom man sitter tett, er det plass til 90 mennesker og en høyvokst visesanger. Etter konserten sto det et lite stykke på trykk med overskriften "Jan Eggum syng på Kolbeinstveit - ein stemningsrapport”. Her kan vi lese blant annet:

Stemma til Jan Eggum finn plass og lagar lyd og ord som gjer at ein sett seg godt til rette på benken og gløymer at den er hard. Veggane tek imot gitarspelet og orda til Jan Eggum, og om litt syng dei som kan songane med på nokre av versa. [...] [...]Eg trur me likar godt at det blir intimt. Det får ikkje bare songane til å krype inn i øyrene våre, men bodskapane om kvifor me ikkje skal kriga og gjera alt om til pengar, det får liksom eit ekstra trykk når dei svevar mot oss frå scenen i løa på Kolbeinstveit. Dei alvorlege orda blandar seg i ei salig og fredfull røre med vitsar og lått, og mannen på scena er sprekkfull av sjølvironi og er eigentleg ganske som oss med tankar og dum angst for så mykje rart (Ramstrøm 2004: 256.)

Forfatterens skildring av konserten med Jan Eggum viser hvordan materialiteten innlemmes som en viktig del av konsertopplevelsen. Veggene tar i mot gitarspillet, skriver hun, og det er ikke hvilke som helst vegger som kan ta imot et gitarspill. Det er slitte vegger, ekte veg- ger, vegger som gjør at budskapet i sangtekstene blir ytterligere betydningsfulle. Materialiteten og den stemningen denne skaper, hjelper Eggum til at tekstene hans ikke blir tomme, men derimot ord til ettertanke.

Tormod, en annen informant, mener også det er noe spesielt med konsertene på Kolbeinstveit. Han er også opptatt av hvordan bygdetunet og bygningene der skaper en spesiell ramme rundt konsertene:

Du er jo på en plass med atmosfære, både før og etter, som også har en betydning. Sikkert og for selve konsertopplevelsen. Du kommer tross alt i en stemning før konserten begynner som sikkert har en betydning,

sier Tormod.

Bygdetunet har en spesiell atmosfere som setter ham i en spesiell stemning. Dette er viktige egenskaper ved bygdetunet som han setter pris på. Hvordan skal man så forstå disse begrepene? Hva innebærer det at Tormod kommer i en spesiell stemning av å kjenne rommets atmosfære? Er dette en egenskap ved materialiteten, eller er det en subjektiv beskrivelse han selv artikulerer? Den tyske filosofen Gernot Böhme har skrevet om atmosfærens ontologi og forsøkt å forklare hva som ligger i begrepet. Ifølge han kan ikke atmosfæren tilskrives verken objektet eller subjektet. Når vi snakker om at røde ting utstråler en varm atmosfære er ikke dette et resultat av at den røde fargen eller den røde tingen er mer eller mindre varmeledende. Det er altså ingen fysiske egenskaper ved objektet som skaper atmosfæren. Men på den andre siden:

Træder vi ind i et rum med en bestemt atmosfære, så er det den vi påvirkes af, så forandres vores stemthed. Det er ikke os, der projicerer vores indre stemthed over i rummet, men omvendt os der gribes og stem- 
50 mes anderledes af rummets specielle atmosfære (Böhme i Albertsen 1999: 6).

Konklusjonen, i følge Böhme, er at atmosfæren befinner seg mellom oss og tingene, mellom subjektet og objektet. I tråd med en tradisjonell kartesiansk dualisme, finnes det ikke noe mellom subjekt og objekt, men det er nettopp dette skillet fenomenologien bryter ned. Heidegger påpeker at mennesket er $\mathrm{i}$ verden og at vi ikke kan løsrives fra, eller forstås uavhengig av denne (jf. Høystad 1994).

Stemningsbegrepet, som både Tormod og forfatteren av konsertskildringen bruker, kan også forklares i denne umiddelbare nærheten mellom menneske og omgivelsene. Nettopp fordi vi til enhver tid er i verden er vi, i følge den danske filosofen Knud Ejler Løgstrup, også til en hver tid påvirket eller stemt av denne: "Sindet er ikke til uden at være stemt. [...] Og uden at være stemt, næret af tingene i deres natur, ville der ingen oplagthed og energi være til een eneste livsytring" (1976: 14), påpeker Løgstrup.

Materialiteten på Kolbeinstveit er meningsbærende i det at den påvirker de besøkendes konsertopplevelse. Samtidig formidlet også informantene at materialiteten og stedet var meningsbærende ved at det la føringer for hvilke musikk som kunne fremføres på bygdetunet. Folkemusikk og visesang passet ifølge informantene godt inn, rock og heavy metal hadde ingen naturlig plass på bygdetunet.

\section{MATERIALITET OG IDENTIET}

I tankegangen rundt etableringen av bygdetuna så vi at gjenstander og hus ble tatt i bruk for å formidle en identitet som kunne bidra til å styrke både den nasjonale og den lokale bevisstheten. Hvordan er det så i dag, kan den samme materialiteten fortsatt ha betydning for de besøkendes identitetskonstruksjon? Både forståelsen og bruken av kulturell identitet er i dag problematisert. Ifølge flere modernitetsteoretikere knytter ikke lenger folk sin identitet til fikserte størrelser som det nasjonale eller det lokale (jf. Featherstone 1991, Giddens 1991, Lyotard 1984). Senmoderne identitetskonstruksjonen kjennetegnes, i følge sosiologen Anthony Giddens, ved at hver enkelt person plukker ut ingredienser de selv vil tilsette i selvidentitetens bakverk (Giddens 1991). Måten en velger råvarene på er også viktig i beskrivelsen av identitetskonstruksjon. For som Featherstone hevder, tilegnes ikke livsstil og identitet lenger fra et sett med fikserte kulturelle aktiviteter og smaker. Livsstil blir til gjennom "the active stylization of life in which coherence and unity give way to the playful exploration of transitory experiences and surface aesthetic effects" (Featherstone 1991: 95).

Ifølge Featherstone er estetikk og materialitet viktig for hvordan vi i dag tilegner oss en livsstil og dermed en identitet, men vil det si at materialitet på bygdetunet også kan være betydningsfullt på tross av at vi i dag befinner oss i en helt annen virkelighet?

Sven, en deltidsbonde i 40-åra, plasserer Kolbeinstveit inn i en klar meningssammenheng når han blir spurt om vi trenger slike steder:

Jeg skal klare meg uten Kolbeinstveit jeg. Jeg forstår en del av den gamle historia, jeg har den med meg. Men hva gjør en da når folk ikke forstår den lenger? Og ikke forstår det som står i veggen der oppe. Det er jo sjel i hver eneste stokk. Jeg vet det. Jeg kjenner det.

Sven identifiserer seg med Kolbeinstveit på mange måter i tråd med hva ungdomslagene 
gjorde hundre år tidligere. Han ser en tydelig linje fra det førmoderne, som han mener bygdetunet formidler, til det jordbruket han selv driver i dag. Sven ser seg selv som en bærer, og en som forstår den gamle bondekulturen på en mer inngående måte enn hva mange andre gjør. Samtidig ser vi at materialiteten i høyeste grad er tilstede i Svens argumentasjon. Gjenstandene på Kolbeinstveit formidler ikke bare historien som representasjoner på datidens driftsmidler. De bærer også med seg en historie som Sven kjenner på kroppen når han er der. Hver eneste stokk har sin sjel og sin stemme, og Sven er i stand til å forstå den.

Sven er ikke alene om å forstå bygdetunet som bærer av en stor fortelling. Et par i 50årene hadde tatt med seg sin gamle mor til Kolbeinstveit. Under omvisningen forsøkte de hele tiden å begeistre damen ved å vise til gjenstander og redskap de trodde hun ville minnes og dermed identifisere seg med. "Har du brukt en sånn", eller "hva brukte dere den til?" spurte de. Svarene fra damen var lunkne og uengasjerte. Selv om hun hadde brukt flere av gjenstandene, hørte de hjemme i en tilbakelagt tid som damen gav uttrykk for at hun ikke lengtet tilbake til. Paret hadde en tydelig forståelse av at damen kunne og ville la seg skrive inn i den samme historien som de plasserte Kolbeinstveit i. Men, på tross av gjentatte forsøk og på tross av at damen var både gammel og norsk, virket det som hun var svært lite villig til å la seg skrives inn i denne.

Etter omvisningen, da damen kom ut på tunet, fikk hun se den gamle dampbåten $\mathrm{D} / \mathrm{S}$ Suldal, som ligger til kai nedenfor bygdetunet. Dette er en båt som gikk i rutetrafikk på vannet fram til det ble bygd vei i 1980. Om ikke damen hadde vist særlig entusiasme tidligere, så gjorde hun det nå. Hun ble blank i øynene samtidig som hun begynte å fortelle om hvor- dan hun som ung pike hadde reist med båten hver påske når de skulle på ferie. Beskrivelsen var lite utadvendt, hun fortalte mest til seg selv, og forsøkte å finne navna på venninnene som hadde vært med på turene. Da hun hadde ramset opp noen navn, konkluderte hun med at det bare var ei av venninne fra påsketurene som fortsatt levde. Øynene gikk da fra å være blanke til å bli våte før tårene begynte å trille. Dette var hennes historie. Det var denne lille historien hun identifiserte seg med, ikke den store, museale historia om fortiden, som vertskapet formidlet og som datra og svigersønnen ville plassere henne inn i.

Litt senere på sommeren besøkte et ektepar fra Hardanger Kolbeinstveit. Kona i ekteparet innledet besøket med å spørre om det var mulig å kjøpe Suldalslefse der. Dette er en lokal kake som damen hadde smakt når hun som barn hadde vært på ferie i bygda. Hun fortalte at hun fortsatt minnes hvor god lefsa var. De, eller rettere sagt mannen, ble enige om at de først skulle få en omvisning på museet før de så skulle drikke kaffe og smake på lefsa. Under hele omvisningen virket damen lite interessert i det vi som guider kunne fortelle. Hun var desto mer utålmodig på stunden etterpå når hun skulle få smake Suldalslefsa. Da omvisningen var ferdig, ville hun umiddelbart sette seg til bords og smake på denne. Hun tok en bit av lefsa og konkluderte raskt med at "Jo da, det var sånn det smakte". Hun kommenterte ikke hvorvidt hun likte kaken, men konstaterte bare at dette var smaken hun minstes fra sin barndom. En slik opplevelse kan med rette betegnes som nostalgi. For som historiker David Lowentahl hevder, "What pleases the nostalgist is not just the relic but his own recognition of it ..."(1985: 8). Den lille lefsa inneholdt en rekke minner som åpenbarte seg idet hun satt tennene i den. På samme måte 

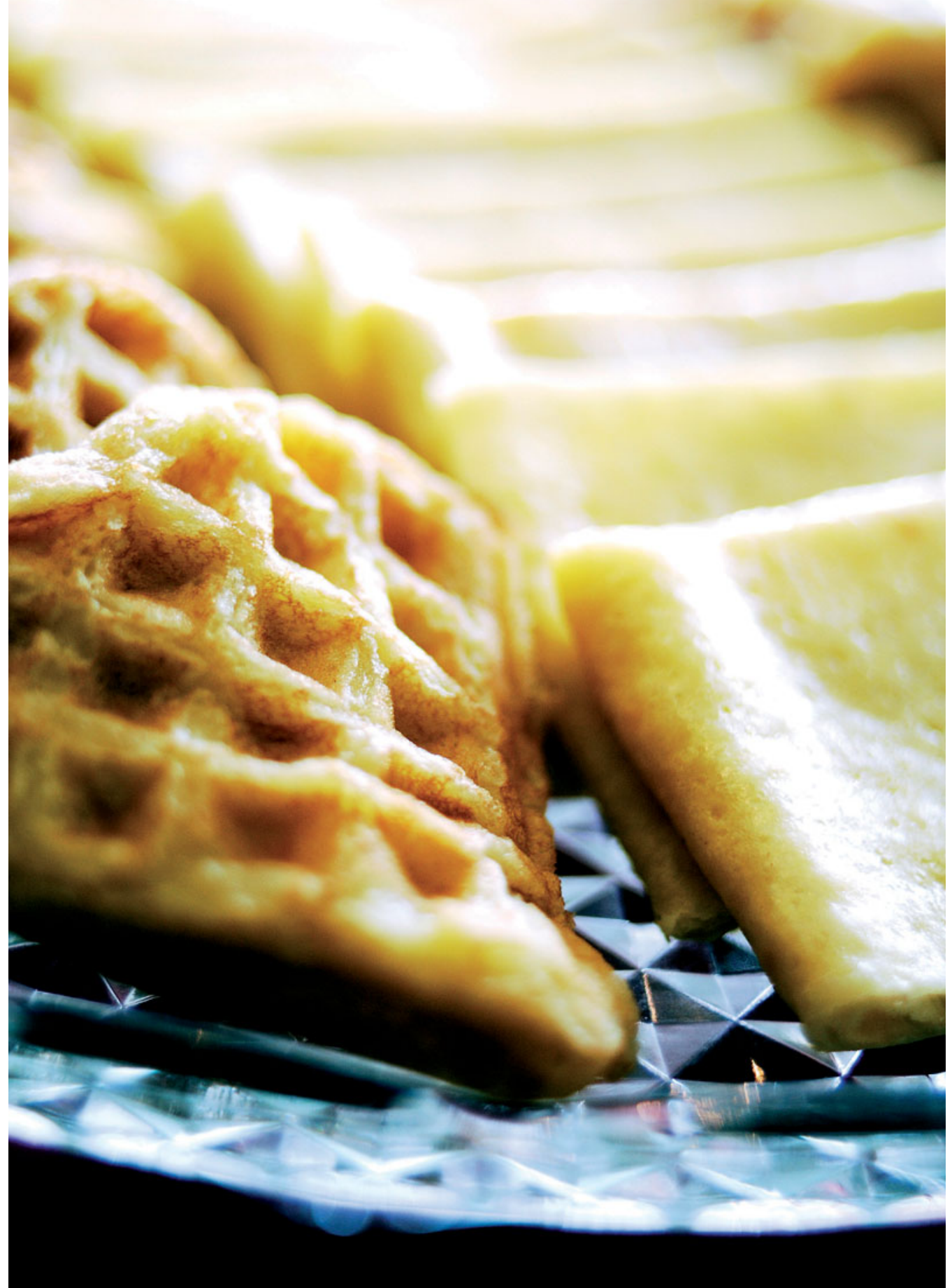

Fig. 2: Ei lefse kan inneholde mye mening for de besøkende på et bygdetun. Den kan også tas i bruk når museet presenteres i bilder. Foto: Anne Lise Nordheim. 
som barndomsminnene til hovedpersonen i Prousts På sporet av den tapte tid dukket opp ved smaken av en madeleinekake (jf. Proust 1999), strømmet minnene til denne damen fram da hun kjente smaken av lefsen. Minner som også for denne kvinnen syntes som en viktig del av hennes selvbiografiske fortelling. Gjennom en sanselig opplevelse fikk hun et kort tilbakeblikk på en opplevelse som betydde noe for henne den gangen, og som fortsatt hadde betydning den dag i dag.

En regntung ettermiddag sommeren 2005 satt noen gjester ved det store "veitlebordet" framfor grua i kjøkkenet på Kolbeinstveit. Denne regntunge sommerdagen er bordet dekket med duk, levende lys, kaffe og vafler. På grua er det god varme. Rundt bordet sitter også Stian, en hjemflytta Suldøl som har fătt seg en god jobb i bygda etter endte studier i Oslo. Det er god stemning og livlig prat da Stian plutselig utbryter: "Når jeg sitter her, er det som å være i hjertet av Suldal”. Det var altså der, i det musealt konstruerte kjøkkenet, med telys fra IKEA, kaffe på termokanne og vafler med Nora-syltetøy at Stian følte han var i hjertet av hjembygda si. For en konservator som til tider gremmes over den manglende autentisiteten i rommet kan det kanskje være vanskelig å tro et slikt utsagn, for Stian var det ramme alvor. For han var dette en opplevelse som gav ham en umiddelbar følelse av tilhørighet. Det er ikke sikkert Stian var klar over at det aldri hadde sett slik ut i Suldal på 1800tallet, men det er heller ikke sikkert at Stian hadde noen spesiell historisk epoke i tankene når han satte ord på sine spontane følelser og dermed knyttet noe av sin identitet til kjøkkenet på Kolbeinstveit. Fra en bygningsantikvars synspunkt er dette stedet en fordreining av historien, og derfor langt fra et autentisk miljø. Autentisitet i kulturminneforvaltningen er knyttet til det som er ekte, troverdig og opprinnelig. "Vanligvis er det et formalbegrep som hører hjemme i en kontekst som vektlegger kildekritikk og vitenskaplig argumentasjon slik vi finner den i historieforskningen", skriver etnologen Ragnar Pedersen om begrepet autentisitet (2000). Likevel er det rimelig å hevde at opplevelsen i kjøkkenet på Kolbeinstveit gav Stian en sterk følelse av autentisitet eller ekthet. Frode Nyeng diskuterer autentisitet som en personlig erfaring i boka $E k$ sistensens filosofi (2003). Her henviser han til Heideggers fenomenologiske tolkning av begrepet der autentisitet kan beskrives som "det gjennomsiktige selvforholdet", eller "egentligheten". Med en slik forståelse av begrepet kan autentisitet vel så gjerne handle om hvem man oppfatter seg som, altså identitet, som en egenskap ved tingene. Innenfor eksistensfilosofien er autentisitet knyttet til egenskaper ved vår vilje og handling. "Ektheten gjelder vår væremåte, ikke vellykkede intellektuelle operasjoner", skriver Nyeng (ibid: 194). Dette samsvarer godt med Stian sin opplevelse. Det syntes ikke å være gjennom grundig refleksjon han kom fram til sin erkjennelse, men gjennom handling. Ved å sitte i rommet, spise vafler og kjenne varmen fra grua.

De empiriske funnene fra studien av de besøkende på bygdetunet gav grunnlag for å hevde at identitetsbygging fortsatt kan være en av flere betydninger bygdetunet kan ha. Det vil si, bygdetunet representerer ikke lenger en stor, moderne fortelling slik de var tiltenkt da de ble etablert rundt århundreskifte og i tiden etter 2. verdenskrig. Bygdetunet kan i dag på ulik måte, og i større eller mindre grad være betydningsfullt for den enkelte besøkende ved at de knytter bygdetunet til sin livshistorie. Erfaringer, lukter, smaker, stemninger og atmosfærer kan på ulikt vis knyttes 
54 til tidligere, betydningsfulle erfaringer, eller som i Stian sitt tilfelle, gi en umiddelbar opplevelse og erkjennelse av å være i hjerte av hjembygda.

\section{DEN LUNEFULLE MATERIALITETEN}

Materialiteten er meningsbærende, men den er også lunefull. Når man på bakgrunn av denne empiriske studien kan konkludere med at de besøkende på Kolbeinstveit også den dag i dag på ulike måter finner mening i museets materialitet, må man samtidig innse at det nødvendigvis ikke er de gjenstandene som museet ønsker å fremheve som er mest verdifulle for de besøkende. Det er heller ikke sikkert at den historien museet gjennom sine guider forsøker å formidle, er den historien som publikum ønsker å høre, eller den som gir dem mest mening.

Når man velger å tolke de besøkenes forhold til materialiteten gjennom en fenomenologisk tilnærming, ser vi hvordan materialiteten erfares subjektiv og ulikt mellom ulike besøkende og kanskje også mellom fagfolk og lekfolk. Den enkelte besøkende legger sin erfaringsverden til grunn for hvordan hun tolker materialiteten og skriver gjerne erfaringene inn i sin egen historie. Dette skaper særskilte utfordringer for formidlingen på et bygdetun. Selv om man fra et faglig ståsted gjerne vil formidle den mest "riktige" fortolkningen av materialiteten, er det viktig at de besøkende selv kan legge sine egne tolkninger og sine egne erfaringer til grunn for møtet. Akkurat som enkelte helst vil være i fred når de kommer inn $\mathrm{i}$ en kirke, og slippe prestens fortolkninger av det hellige rom, kan det være at enkelte av de besøkende helst vil oppleve bygdetunet på sin egen måte.

Samtidig ser vi også at materialiteten har en rekke felles konnotasjoner som deles av de fleste. Dette så vi blant annet i hvordan konsertgjestene hadde en felles forståelse for hvordan materialiteten påvirket musikken, men det blir enda tydeligere dersom man søker å finne en felles forståelse av bygdetunet. For selv om bygdetunet kan romme svært mange ulike forståelser, er det én forståelse som fremstår som gjennomgående: Den moralsk gode.

\section{DEN GODE MATERIALITETEN}

En sommerdag i juli kom to barn med sine besteforeldre inn i tunet på Kolbeinstveit. Bestemora hadde sett hesja som sto nedenfor hovedhuset, og fortalte oss at hun hadde sagt til barna at de kunne krype gjennom den. Hun fortalte med stor entusiasme hvordan hun selv hadde gjort dette som barn, og sa at det var noe av det kjekkeste hun husket fra barndommen. Kryping gjennom hesjene ble ikke alltid like godt mottatt av de voksne den gangen, kunne hun huske. Dette gjorde nok kanskje opplevelsen ekstra spennende, men de gode minnene damen hadde, forklarte hun med den gode lukten, og følelsen av høy på alle kanter. Jeg fortalte da at barna gjerne kunne hoppe i høyet som vi hadde på låven. Bestemora reagerte umiddelbart med å si "JA!", som om det var hun som skulle få hoppe. "Det må dere gjøre", sa hun og sendte barna opp dit.

Hva er det så med denne opplevelsen av å hoppe i høyet? - En tilsvarende aktivitet finner man svært mange steder, men der er høyet byttet ut med plastballer. Likevel er det noe helt annet å hoppe i plastballer enn hva det er å hoppe i høyet. Disse to aktivitetene har helt forskjellige kulturelle referanser. Et rom fullt av plastballer finner man som regel på kjøpesenter og andre steder der man har behov for å "parkere barna" mens man i ro og fred kan gå 
og handle. "Hopping i høyet" gir helt andre konnotasjoner. Et søk på internett viste at aviser, turistportaler, kommuner og besøksgårder benytter seg av begrepet, og forhøyer det som noe ekte eller herlig. Søket viste at det også ga erotiske konnotasjoner, men også her var det utelukkende positive aktiviteter det beskrev.

Høy kan være et godt eksempel på den gode materialiteten man finner på et bygdetun. Selv om det kan være både farlig og usunt å hoppe i høyet (man kan treffe en høygaffel, eller rammes av astma), beskrives dette som noe særskilt godt. Det samme gjør en rekke andre opplevelser på bygdetunet, ikke minst omgang med dyr.

Da jeg ba Per, en av mine informanter, nevne en spesiell opplevelse på Kolbeinstveit, var det dyrene og vertskapet han trakk fram: "Det som hadde gitt meg mest, var å se at det var liv i bygningene, som dere har klart å skape. Det å se at det går husdyr der, og se at dere mater og forer dem", sa Per. Det var nok ikke husdyrs ernæring han var mest opptatt av, men derimot det tette forholdet mellom mennesker og dyr på bygdetunet.

Dersom man skal forsøke å finne én felles betydning de besøkende legger i bygdetunet, så må det være "det gode liv på landet". Det å oppleve en bit av det gode liv på landet synes å være langt viktigere for de besøkende enn å lære noe om fortiden. Men det er ikke kun de besøkende som fortolker bygdetunet slik. Da min kone og jeg ble tilbudt jobb som boende vertskap på en museumsgård, var det en drøm som gikk i oppfyllelse for oss begge. Hele våren, før den første sommeren, så jeg fram til hvordan hun og jeg skulle gå barbeinte i gresset, mate dyr, slå med ljå og grave i jorda. Alt dette i en ramme av sol og varme. Når Ryfylkemuseet, som eier og driver av bygdetunet, framstiller Kolbeinstveit i bøker og på nettsi- der, trekkes det i det skriftlige materialet fram hvem som bodde på garden, og hvilke stilling disse hadde i Suldal. Ser man derimot på den visuelle presentasjonen av Kolbeinstveit, er situasjonen en annen. På hjemmesidene til Ryfylkemuseet er det tatt med et bilde fra Kolbeinstveit. Her ser vi vertskapet sittende på huk med gamle klær. Framfor går en hane og et lam. På framsiden av museets årbok er det også vertskapet som er avbildet. Her står de i vadmelsbukse, busserull og sid kjole foran en hesje, med innhuset i bakgrunnen. Bildet er også brukt på plakater, trykksaker og en utstilling om Kolbeinstveit. Media og reiselivets framstilling trekker også fram det gode i materialiteten på Bygdetunet. Lyse, fargesterke bilder viser hvordan unge, glade mennesker lever tett innpå en førmoderne idyll som er konstruert etter beste Disney-idealer. Alle sanser skal tas i bruk for å erfare den moralsk gode fortiden.

Fenomenologien kan gi oss mye kunnskap om forholdet mellom materialitet og mening, mellom bygdetunet og de besøkende. Likevel kommer man ikke utenom at den betydningen og den mening de besøkende legger i bygdetunet i dag også er preget av felles kulturelle, eller diskursive fortolkninger. Det gode liv på landet kan være en slik. Dette er en forestilling man finner i en rekke tv-serier, glansende magasiner, reportasjer og lignende. Både internasjonalt og her i Norge brer kulturarvturismen (heritage industry) om seg. I blader som blant annet Lev Landlig og Country Living kan man lære hvordan man skaper idyll på landet, og gjennom serier som bonderomantikk og Farmen lærer man også verdien at et slikt liv. Det er også nærliggende å se på denne trenden i tråd med de siste årenes fokus på miljø og økologi, et fokus som har blitt implementert i store deler av samfunnsfor- 


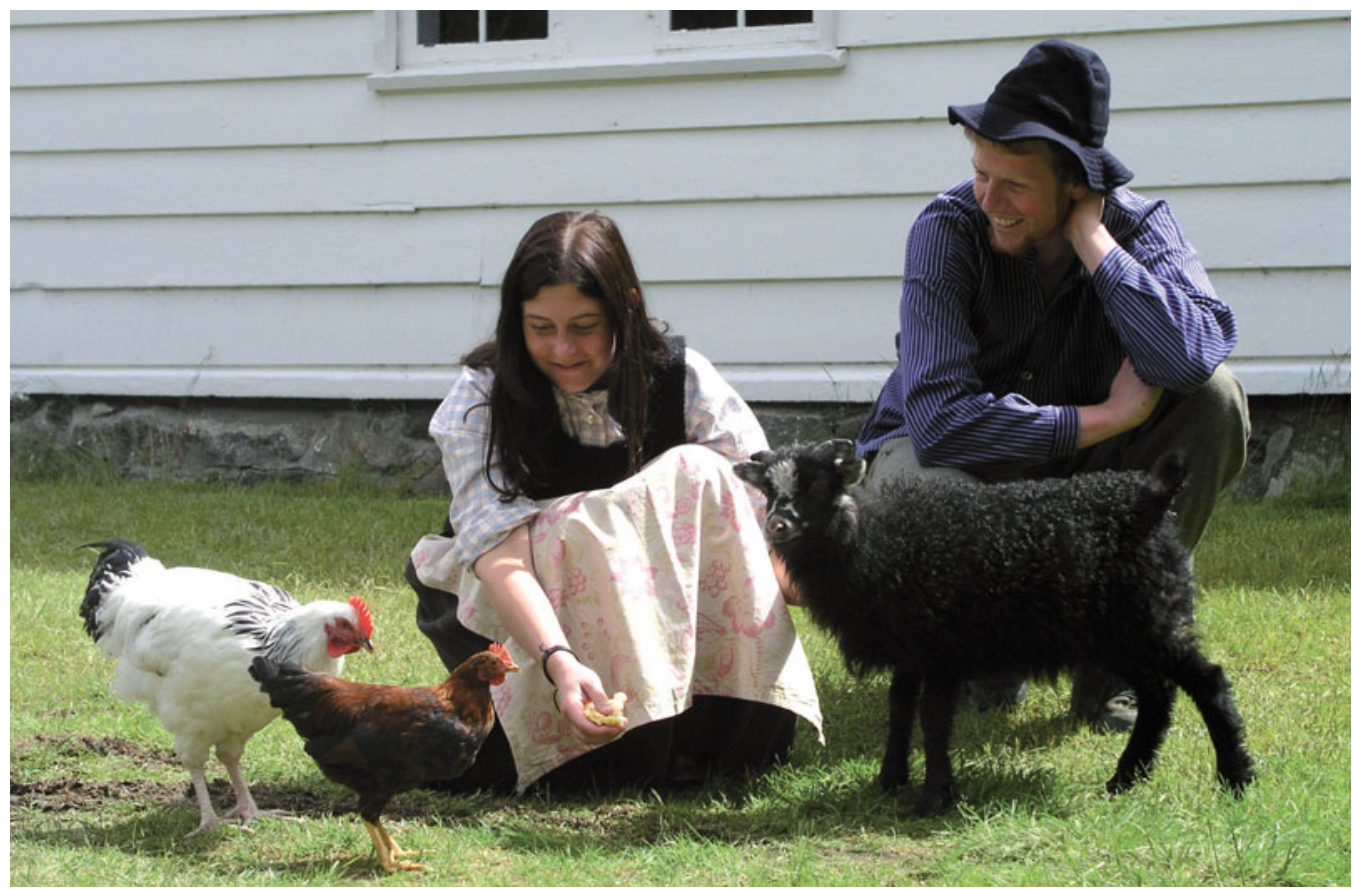

Fig. 3: Positive unge mennesker og glade frittgående dyr er en viktig del av den gode materialiteten som bygdetunet presenterer. Bildet er hentet fra Ryfylkemuseets ärbok fra 2004. Foto: Roy Høibo.

mingen i dag. Kanskje er den grønne fortelingen i dag vel så sterk som den nasjonale fortellingen var da bygdetuna ble etablert?

Det økologiske perspektivet er igjen blitt aktualisert i museumsdebatten, og inkludert som en av de viktigste utfordringene på museumsområdet framover (jf. St.meld. nr. 22 (1999-2000) 1999). Slik sett kan bygdetunet igjen bli en viktig aktør i arbeidet med å skape et slikt engasjement. På den andre siden kan man hevde at dyrkningen av det gode liv vil være stikk i strid med historieformidling fra tiden da man levde slik. Kanskje skulle man heller presentert lukten av skit og smaken av lett fordervet mat $\mathrm{i}$ et skittent og kaldt hus dersom man ønsket å formidle fortiden? Uan- sett hva man velger, vil materialiteten fortsatt være det som bærer formidlingen på bygdetunene.

\section{NOTER}

1. I St. Meld. nr. 22 (1999-2000) ble det tatt til ordet for en museumsreform der man ønsket en konsolideringsprosess hvis målsetning var at det skulle være om lag 100 museumsenheter i Norge. Denne prosessen ble gjennomført de påfølgende årene og en rekke museer ble underlagt en felles administrativ og faglig ledelse.

2. Museets ledelse ser det også som interessant å bevare dette rommet nettopp for å formidle den 
tankegangen som eksisterte da bygdetunet ble etablert. Dette inkluderes derfor i formidlingen.

\section{LITTERATUR}

Albertsen, N. (1999). Urbane atmosfærer. Sociologi i dag, 4/1999

Bærenholdt, J. O. (2007). At forbinde steder. Turistopplevelser på farten. Nordisk museologi, 2/2007

Featherstone, M. (1991). Consumer culture and postmodernism. London: Sage.

Frykman, J. og Gilje, N. (2003). Being there: new perspectives on phenomenology and the analysis of culture. Lund: Nordic Academic Press.

Giddens, A. (1991). Modernity and self-identity: self and society in the late modern age. Cambridge: Polity Press.

Hegard, T. (1984). Romantikk og fortidsvern: historien om de forste friluftsmuseene i Norge. Oslo: Univ.forl.

Holmboe, G. (2004). Hus og heim. I: Høibo, R. (red.) Kolbenstveit, s. 35-55. Sand: Ryfylkemuseet.

Høystad, O. M. (1994). Det menneskelege og naturen: innforing i filosofisk antropologi. Oslo: Samlaget.

Ingold, T. (2000). The perception of the environment. Essays on livelihood, dwelling and skill. London: Routledge.

Kleppe, B. (2007). Der gresset er gront og toalettene rene. Om bygdetunets betydning i dag. $\mathrm{B} ø: \mathrm{Høg}-$ skolen i Telemark.

Lowenthal, D. (1985). The past is a foreign country. Cambridge: Cambridge University Press.

Lyotard, J.-F. (1984). The postmodern condition. A report on knowledge. Manchester: Manchester University Press.

Løgstrup, K. E. (1976). Metafysik. Copenhagen: Gyldendal.

Maure, M. og Gjestrum, J. A. (1988). Økomuseumsboka - Identitet, økologi, deltakelse. Ei arbeidsbok om ny museologi. Tromsø: Norsk ICOM.

Merleau-Ponty, M. (1962). Phenomenology of perception. London: Routledge.
Nerbøvik, J. (1999). Norsk historie 1860-1914. Eit bondesamfunn i oppbrot. Norsk historie. Oslo: Samlaget.

Nyeng, F. (2003). Eksistensens filosofi. Om frihet, angst og mening i eget liv. Oslo: Abstrakt forlag.

Pedersen, R. (2000). Autentisitet og kulturminnevern. En diskusjon om kulturminnevernets verdigrunnlag. I: b. 25(2000)nr 1/2 Dugnad, s. S. 2148. Oslo: Novus.

Proust, M. (1999). På sporet av den tapte tid. [Oslo]: Gyldendal.

Ramstrøm, A. K. (2004). Jan Eggum syng på Kolbeinstveit - Ein stemningsrapport. I: Høibo, R. (red.) b. 2004 Kolbenstveit, s. 156. Sand: Ryfylkemuseet.

St.meld. nr. 22 (1999-2000) Kjelder til kunnskap og oppleving. Om arkiv, bibliotek og museum $i$ ei IKT-tid og om bygningsmessige rammevilkår på kulturområdet. Oslo: Kultur- og kirkedepartementet.

Talleraas, L. E. F. (2009). Et uregjerlig mangfold? Lokale og regionale museer som saksfelt i norsk kulturpolitikk 1900 - cirka 1970 Umeå: Umeå Universitet.

Ågotnes, H.-J. (2000). Vern, vitskap og samfunn : om kulturvernet sine meiningsamanhengar. I: Dugnad, b. 25(2000)nr 1/2, s. S. 69-90. Oslo: Novus.

*Bärd Kleppe er MA i kulturstudier fra Høgskolen $i$ Telemark og jobber som kulturforsker ved Telemarksforsking.

Address: Telemarksforsking(Telemark Research Institute)

Postboks 43833 Bø i Telemark, Norway

E-mail: kleppe@tmforsk.no

Web: http://www.telemarksforsking.no 